Southern Methodist University

SMU Scholar

\title{
Mortgage Modification and Strategic Behavior: A Contrarian Reading of the Countrywide Financial Corporation Settlement
}

Gregory S. Crespi

Southern Methodist University, Dedman School of Law

\section{Recommended Citation}

Gregory S. Crespi, Mortgage Modification and Strategic Behavior: A Contrarian Reading of the Countrywide Financial Corporation Settlement (2011)

This document is brought to you for free and open access by the Faculty Scholarship at SMU Scholar. It has been accepted for inclusion in Faculty Journal Articles and Book Chapters by an authorized administrator of SMU Scholar. For more information, please visit http://digitalrepository.smu.edu. 
MORTGAGE MODIFICATION AND STRATEGIC BEHAVIOR:

A CONTRARIAN INTERPRETATION OF THE COUNTRYWIDE

FINANCIAL CORPORATION SETTLEMENT

by

Gregory Scott Crespi ${ }^{1}$

Preliminary Draft

August 28, 2011 
Countrywide Financial Corporation entered into a widely publicized settlement agreement with a number of state attorney generals in October of 2008 under which it agreed to modify all subprime mortgages that it serviced throughout the nation, beginning in December, 2008. ${ }^{2}$ A centerpiece of this settlement was Countrywide's commitment to offer expedited and unsolicited loan modifications to borrowers who were at least 60 days delinquent on their loans. ${ }^{3}$ Christopher Mayer, Edward Morrison, Thomasz Piskorski and Arpit Gupta, all of Columbia University, have recently published a comprehensive paper in the Law \& Finance eJournal (hereinafter referred to as the "Mayer Study" or the "Study") in which they attempt to demonstrate that this settlement led to significantly higher rates of mortgage default among those borrowers who had the financial capability to continue to make their mortgage payments, so as to allow them qualify for these expedited modifications. ${ }^{4}$ Specifically, they found that Countrywide's monthly mortgage delinquency rate increased by $13 \%$ immediately after the settlement's announcement, and that the class of borrowers whose default rates increased the most were those persons with substantial liquidity for whom mortgage loan default was "strategic," i.e., primarily a matter of choice rather than of financial necessity. ${ }^{5}$

The Mayer Study is sophisticated and carefully done, and is likely to prove to be influential among policymakers, and I recommend that the interested reader review the Study in its entirety. In this brief article I will only offer a single criticism of this Study, one more of its implicit premises than of its methodology or conclusions. I agree with the authors of the Study that this settlement provides an excellent opportunity to assess the extent of borrower responsiveness to loan modification opportunities. ${ }^{6}$ I also agree that the Study convincingly 
demonstrates that rates of strategic default are sensitive to the perceptions of borrowers that defaults may lead to attractive loan modifications rather than to foreclosures. ${ }^{7}$ The problem that I have with the Mayer Study is with its implicit assumption that strategic defaults by underwater homeowners who have the capability to continue to make their mortgage payments are a bad thing, imposing on balance net social costs, ${ }^{8}$ and that mortgage modification programs should ideally be designed so as to discourage such strategic behavior ${ }^{9}$ even if the constraints imposed to accomplish this limit to some extent the effectiveness of the programs in reducing the numbers of underwater homeowners or foreclosure rates. ${ }^{10}$

I strongly disagree with this assumption. In my opinion we will not have a significant recovery in the housing sector or in the national economy more generally until a large proportion of the millions of currently underwater homeowners are able to obtain principal-reducing loan modifications from their mortgage loan servicers that would be sufficient to eliminate their negative equity positions. These principal-reducing loan modifications, if done on a large scale, would sharply reduce the number of foreclosures and thereby mitigate the various adverse social consequences of high foreclosure rates. Currently, however, borrowers who seek mortgage loan modifications are generally only able to obtain at best modifications that merely reduce the loan interest rate and/or extend the loan repayment period, or that simply roll any payment arrearages into the unpaid mortgage balances. Because of the literally hundreds of billions of dollars of capital losses that would result in the aggregate for mortgage lenders from engaging in the millions of principal-reducing loan modifications that would be necessary to largely eliminate the vast overhang of negative equity positions, losses that the federal government is most 
unlikely to be willing to substantially subsidize through a new bailout program, given its current difficult financial circumstances and political gridlock, I do not believe that loan servicers will be willing to enter into such principal-reducing modifications on a sufficiently large scale to resolve the underwater homeowner problem until they have no real choice in the matter. This will be the case only once those many solvent underwater homeowners who have the financial capability to continue to make their payments evidence en masse a willingness to strategically default and go through foreclosure, imposing large foreclosure sale losses upon lenders if such principalreducing loan modifications that would in general result in significantly smaller losses to lenders are not first granted.

In my view the best way to resolve the underwater homeowner problem is therefore a combination of governmental policy measures that will, first, encourage large numbers of solvent underwater homeowners to strategically default and, second, encourage mortgage servicers to respond to such strategic defaults with principal-reducing loan modifications that will lead to borrower mortgage payments being resumed, rather than to respond by initiating foreclosure proceedigns. I have recently published a comprehensive article in the Santa Clara Law Review where I set forth this argument in some detail, and where I offered a number of recommendations as to how such strategic defaults and subsequent principal-reducing loan modifications could be best encouraged and facilitated. ${ }^{11}$ I recognized in that article that most policymakers and influential commentators in this area disagree with me, and generally take the somewhat sanctimonious position that strategic defaults are irresponsible and perhaps even immoral borrower behavior that should not be encouraged, and that far more modest governmental loan 
modification policy initiatives that do not encourage strategic defaults will be sufficient to resolve the problem. They continue to adhere to these views despite the continuing failure to date of those various quite modest initiatives to lead to appreciable numbers of principalreducing loan modifications. ${ }^{12}$ I also offered in that article some thoughts regarding the various sources of this persistent reluctance on the part of policymakers and most leading commentators to encourage strategic defaults. ${ }^{13}$

I refer the interested reader to that prior article where I have elaborated upon those arguments, and I will not repeat them here. My sole point in this brief article is simply to note that the Mayer Study shows that this conventional wisdom that strategic defaults should not be encouraged remains alive and well, and that this view continues to constrain policy formulation and analysis. To their credit, Mayer and his co-authors have carried out a sophisticated descriptive study of the strategic default consequences of the terms of the Countrywide settlement. The Study surely provides useful guidance for policymakers whether they regard encouraging strategic defaults as a pitfall to be avoided in policy design or, as I do, as the sin qua nom of a successful strategy to reduce the number of underwater homeowners. However, the authors' view regarding the undesirability of strategic defaults badly undercuts their ability to offer any useful policy recommendations on the basis of their findings.

The Mayer Study assumes throughout, without supporting discussion, that an increased number of strategic defaults will somehow lead to net "economic costs,"14 and it then concludes with a very brief recommendation that loan modification policies should consequently be 
designed so as to discourage and limit the opportunity for such strategic behavior, whenever this can be accomplished without unduly impeding the achievement of other policy goals such as reducing the number of underwater homeowners or foreclosure rates. ${ }^{15}$ The closing message of the Study is that the fairly simple eligibility criteria of the Countrywide settlement for expedited loan modifications (60 days in delinquency, without regard to ability to pay) encouraged strategic default, and that the use of more complex loan modification eligibility criteria that would screen out those persons with the capability of continuing to make their payments might well be a superior approach, all things considered, even if those criteria impeded somewhat achieving other program goals. But if one regards encouraging strategic default en masse as a necessary part of the solution to the underwater homeowner problem, as I do, then the lessons of the Countrywide settlement are not cautionary lessons about difficult trade-offs to be balanced in formulating loan modification eligibility criteria, as the Mayer Study suggests, but are instead more encouraging messages about the advantages of using simple, "manipulable"16 loan modification eligibility criteria that would facilitate strategic defaults. The Mayer Study's implicit normative stance disfavoring strategic defaults renders its analysis less useful than it might have been for helping policy makers draw the correct conclusions from the Countrywide settlement experience for the design of future policies to address the severe and persisting problems posed by the millions of underwater homeowners.

\footnotetext{
${ }^{1}$ Professor of Law, Southern Methodist University. J.D., Yale Law School, Ph.D., University of Iowa.
} 
${ }^{2}$ Christopher Mayer, Edward Morrison, Thomas Piskorski \& Arpit Gupta, "Mortgage Modification and Strategic Behavior: Evidence From a Legal Settlement with Countrywide," 3 Law \& Fin. eJour. (May 23, 2011), at 5 (hereinafter the "Mayer Study"). Prior to this publication the paper had been distributed earlier as a working paper, both as Columbia Law and Economics Working Paper No. 404, May 16, 2011, and as NBER Working Paper No. 17065, May 2011.

${ }^{3}$ Id.

${ }^{4}$ Id. at $33-34$.

${ }^{5}$ Id. at Abstract.

${ }^{6}$ Id. at 5.

${ }^{7}$ Id. at Abstract.

${ }^{8}$ Id. at 34.

${ }^{9}$ Id. at Abstract.

${ }^{10}$ Id. at $4-5$.

${ }^{11}$ Gregory Scott Crespi, "The Trillion-Dollar Problem of Underwater Homeowners: Avoiding a New Surge of Foreclosures by Encouraging Principal-Reducing Loan Modifications," 51 Santa Clara L. Rev. 153 (2011). An earlier June, 2010 draft of this article is also electronically available on the Social Science Research Network at http://papers.ssrn.com/sol3/papers.cfm?abstract/id_1632611.

12 Crespi, id., at 178-88.

13 Id. At least one leading commentator is in full accord with my call for encouraging strategic defaults so as to induce larger numbers of principal-reducing loan modifications. See Brent White, "Underwater and Not Walking Away: Shame, Fear, and the Social Management of the Housing Crisis," 45 Wake For. L. Rev. 971 (2101).

${ }^{14}$ Mayer Study, supra n. 2, at 34.

${ }^{15} \mathrm{Id}$.

${ }^{16} \mathrm{Id}$. 